\title{
OPTIMISASI PRODUKSI ENZIM LAKASE PADA FERMENTASI KULTUR PADAT MENGGUNAKAN JAMUR PELAPUK PUTIH Marasmius sp. : PENGARUH UKURAN PARTIKEL, KELEMBAPAN, DAN KONSENTRASI $C u$
}

\author{
Cornelius Damar Hanung a, Ronald Osmond a, Hendro Risdianto b 1 , \\ Sri Harjati Suhardi ${ }^{c}$, Tjandra Setiadi a \\ a Program Studi Teknik Kimia - Fakultas Teknologi Industri - Institut Teknologi Bandung \\ Gedung Labtek X, Jl. Ganesa 10, Bandung 40132, Indonesia \\ ${ }^{\mathrm{b}}$ Balai Besar Pulp dan Kertas, Kementerian Perindustrian \\ Jl. Raya Dayeuhkolot 132, Bandung 40258, Indonesia \\ ' Sekolah Ilmu dan Teknologi Hayati - Institut Teknologi Bandung \\ Gedung Labtek XI, Jl. Ganesa 10, Bandung 40132, Indonesia \\ ${ }^{1}$ hendrorisdianto@yahoo.com
}

Diterima : 04 Juni 2013, Revisi akhir : 18 November 2013, Disetujui terbit : 02 Desember 2013

\section{OPTIMISATION OF LACCASE PRODUCTION IN SOLID STATE FERMENTATION USING WHITE ROT FUNGI OF Marasmius sp. : INFLUENCE OF PARTICLE SIZE, MOISTURE CONTENT, AND CU CONCENTRATION}

\begin{abstract}
White rot fungi of Marasmius sp. is a fungus which produce laccase in high activity.Laccase is one of the ligninolityc enzymes that capable to degrade lignin. This ability can be used for the pretreatment of lignocellulosic materials in the bioethanol production. Laccase was produced in flask by batch process using Solid State Fermentation (SSF). The optimisation was conducted by statistically of full factorial design. The particle size, moisture content, and $\mathrm{Cu}$ concentration were investigated in this study. Rice straw was used as solid substrate and the glycerol was used as the carbon sources in modified Kirk medium. The results showed that particle size of rice straw did not affect significantly to the enzyme activity. The highest laccase activity of $4.45 \mathrm{IU} / \mathrm{g}$ dry weight was obtained at the moisture content of $61 \%$ and $C u$ concentration of $0.1 \mathrm{mM}$.
\end{abstract}

Keywords: laccase, Marasmius sp., optimisation, rice straw, solid state fermentation

\begin{abstract}
ABSTRAK
Jamur pelapuk putih, Marasmius sp. merupakan jamur yang menghasilkan enzim lakase dengan aktivitas tinggi. Lakase merupakan enzim ligninolitik yang dapat mendegradasi lignin. Kemampuan ini dapat digunakan untuk proses pengolahan awal bahan lignoselulosa pada pembuatan bioetanol. Produksi lakase dilakukan dalam labu dengan modus batch menggunakan fermentasi kultur padat. Optimisasi produksi enzim lakase dengan metode fermentasi padat dilakukan dengan rancangan percobaan faktorial penuh. Pengaruh ukuran partikel, kelembapan, dan konsentrasi $\mathrm{Cu}$ diuji dengan medium penyangga jerami dengan menambahkan gliserol dalam medium Kirk termodifikasi sebagai sumber karbon. Penelitian ini menunjukkan bahwa ukuran jerami tidak berpengaruh signifikan terhadap aktivitas enzim. Aktivitas enzim lakase maksimum terjadi pada saat kelembapan $61 \%$ dan konsentrasi $\mathrm{Cu} 0,1 \mathrm{mM}$ dengan aktivitas enzim lakase/berat kering tertinggi mencapai 4,45 IU/g.
\end{abstract}

Kata kunci: lakase, Marasmius sp., optimisasi, jerami, fermentasi kultur padat 


\section{PENDAHULUAN}

Penurunan persediaan minyak bumi di dunia memiliki dampak besar terhadap penurunan ketersediaan energi yang dibutuhkan oleh masyarakat. Bioetanol merupakan salah satu sumber energi alternatif yang dapat menjadi padanan sumber energi minyak bumi tersebut. Saat ini, bioetanol yang dikembangkan berbasis pada bahan biomassa yang berbasis lignoselulosa. Bahan lignoselulosa memiliki komponen penyusun lignin, selulosa dan hemiselulosa (Sierra dkk., 2010). Selulosa dalam biomassa tersebut dapat difermentasi lebih lanjut menjadi bioetanol.

Indonesia sebagai negara agraris memiliki bahan biomassa yang melimpah. Bahan biomassa ini dapat diperoleh dari limbah industri pertanian seperti jerami, tandan kosong kelapa sawit, bagas, dll. Indonesia ratarata mampu menghasilkan jerami dan sekam sebanyak 80 juta ton per tahun sebagai limbah pertanian (www.litbang.deptan.go.id). Produksi jerami yang cukup tinggi berpotensi menjadi salah satu bahan baku bioetanol generasi kedua. Jerami sebagai bahan lignoselulosa, memiliki kandungan lignin 18\%, hemiselulosa 24\%, dan selulosa 32,1\% (Sanchez, 2009).

Proses konversi jerami menjadi bioetanol memiliki kendala karena keberadaan senyawa lignin. Senyawa lignin merupakan komponen dengan struktur kuat yang menyelubungi selulosa dan hemiselulosa (Sanchez, 2009). Senyawa lignin ini perlu dihilangkan terlebih dahulu dengan pengolahan awal yang dapat dilakukan dengan cara fisik, kimia, dan biologis.

Salah satu pengolahan awal biologis adalah penggunaan enzim lakase (E.C. 1.0.10.3.2). Enzim lakase diproduksi oleh berbagai jenis jamur dan tumbuhan tingkat tinggi (Mayer dan Staples, 2002). Jamur pelapuk putih sudah diketahui sebagai kelompok jamur yang mampu mendegradasi lignin dengan menghasilkan enzim lakase (Sanchez, 2009). Penelitianpenelitian sebelumnya menunjukkan bahwa Marasmius sp. merupakan jamur pelapuk putih yang berpotensi dalam menghasilkan enzim lakase (Risdianto dkk., 2012).

Gliserol sebagai salah satu sumber karbon telah diteliti oleh Risdianto dkk. (2011) dan menghasilkan aktivitas lakase yang hampir setara dengan sumber karbon glukosa.
Gliserol merupakan produk samping produksi biodiesel yang saat ini sedang dikembangkan sebagai salah satu sumber energi untuk substitusi bahan bakar fosil. Jumlah gliserol yang melimpah akibat produksi biodiesel akan menjadi masalah karena tidak dapat dibuang langsung ke lingkungan. Salah satu penggunaan gliserol adalah sebagai sumber karbon pertumbuhan mikroorganisme (Da Silva dkk, 2009). Penelitian ini bertujuan untuk optimisasi faktor-faktor penting dalam produksi lakase dengan fermentasi kultur padat menggunakan sumber karbon gliserol yaitu ukuran jerami, kelembapan awal, dan konsentrasi $\mathrm{Cu}$.

\section{BAHAN DAN METODE}

\section{Mikroorganisme}

Mikroorganisme yang digunakan adalah jamur pelapuk putih yaitu Marasmius sp., yang merupakan koleksi Pusat Ilmu Hayati ITB dipelihara dalam medium agar miring (PDA).

\section{Bahan Lignoselulosa}

Bahan lignoselulosa sebagai bahan penyangga yang digunakan adalah jerami yang dipotong-potong dengan ukuran $0,5 \mathrm{~cm}$, $2,5 \mathrm{~cm}$, dan $4 \mathrm{~cm}$. Jerami yang digunakan berdasarkan penelitian Risdianto dkk. (2012) yang menggunakan ukuran $3 \mathrm{~cm}$ pada produksi lakase.

\section{Kultivasi}

Substrat padat sebanyak 7 gram dimasukkan ke dalam labu refluks $250 \mathrm{~mL}$ dan direndam dengan medium Kirk termodifikasi sebanyak $50 \mathrm{~mL}$ kemudian disterilisasi menggunakan autoclave pada temperatur $121^{\circ} \mathrm{C}$ selama 20 menit. Komposisi medium Kirk termodifikasi yang digunakan adalah gliserol $1 \% \mathrm{v} / \mathrm{v}, \mathrm{KH}_{2} \mathrm{PO}_{4} 1,7 \mathrm{~g} / \mathrm{L}$, $\mathrm{MgSO}_{4} \cdot 7 \mathrm{H}_{2} \mathrm{O} \quad 0,4 \mathrm{~g} / \mathrm{L}, \quad \mathrm{CaCl}_{2} \quad 0,09 \mathrm{~g} / \mathrm{L}$, natrium asetat 2,3 $\mathrm{g} / \mathrm{L}$, diammonium tartrat $0.4 \mathrm{~g} / \mathrm{L}, \mathrm{MnCl}_{2} 0.02 \mathrm{~g} / \mathrm{L}$, ekstrak ragi $0,3 \mathrm{~g} / \mathrm{L}$, $\mathrm{H}_{2} \mathrm{MoO}_{4} \quad 0,007 \mathrm{~g} / \mathrm{L}, \mathrm{MnSO}_{4} \cdot 4 \mathrm{H}_{2} \mathrm{O} 0,01 \mathrm{~g} / \mathrm{L}$, $\mathrm{ZnSO}_{4} \cdot 7 \mathrm{H}_{2} \mathrm{O} 0,006 \mathrm{~g} / \mathrm{L}$ dan $\mathrm{Fe}_{2}\left(\mathrm{SO}_{4}\right)_{3} 0,007 \mathrm{~g} / \mathrm{L}$. $\mathrm{CuSO}_{4} \cdot 7 \mathrm{H}_{2} \mathrm{O}$ yang digunakan dalam medium Kirk bervariasi yaitu 0,$024 ; 0,050$,dan 0,075 g/L. Setelah dingin, kultur jamur pada media PDA dengan ukuran $2 \mathrm{~cm} \times 2 \mathrm{~cm}$ diinokulasikan 
secara aseptis ke dalam labu refluks. Kultivasi dijalankan selama 10 hari. Tiap tempuhan dilakukan dengan replikasi duplo.

\section{Ekstraksi Lakase}

Analisis aktivitas enzim tiap hari diawali dengan ekstraksi enzim dari kultur jamur menggunakan larutan penyangga asetat $\mathrm{pH} 4,6$ sebanyak $50 \mathrm{~mL}, 100 \mathrm{~mL}$, dan $150 \mathrm{~mL}$ pada shaker dengan kecepatan 100 rpm selama 1 jam. Larutan dan substrat didekantasi dari labu dan dipindahkan kedalam tabung sentrifugasi dan didinginkan dalam lemari es untuk menghindari rusaknya enzim karena panas yang ditimbulkan dari proses sentrifugasi. Larutan yang telah didinginkan kemudian disentrifugasi selama 10 menit dengan kecepatan $6000 \mathrm{rpm}$. Volume optimum larutan penyangga digunakan untuk percobaan selanjutnya.

\section{Analisis Aktivitas Lakase}

Pengukuran aktivitas enzim dilakukan dengan cara memasukkan supernatan contoh sebanyak $60 \mu \mathrm{L}$ ke dalam $1140 \mu \mathrm{L}$ larutan 0,4 mM ABTS (2,2-azino-di-[3-ethyl-benzothiazolin- 6-sulphonic acid]) dalam larutan penyangga asetat ( $\mathrm{pH} \mathrm{4,6)} \mathrm{(Niku-Paavola} \mathrm{dkk.,}$ 1988) yang terdapat di dalam kuvet selanjutnya campuran supernatan dan ABTS dikocok agar tercampur homogen. Absorbansi radikal kation diamati pada panjang gelombang $420 \mathrm{~nm}$ $\left(\varepsilon_{\mathrm{mM}}=36 \mathrm{mM}^{-1} \mathrm{~cm}^{-1}\right)$ selama lima menit menggunakan spektrofotometer Genesis $10 \mathrm{UV}$ Visible. Perubahan absorbansi radikal kation diamati setiap menit selama 5 menit. Satu unit aktivitas didefinisikan sebagai jumlah enzim yang dapat mengoksidasi $1 \mu$ mol ABTS tiap menit pada suhu $28^{\circ} \mathrm{C}$.

\section{Analisis Konsentrasi Protein}

Pengujian protein dilakukan dengan menggunakan larutan Bradford. Sebanyak $100 \mu \mathrm{L}$ supernatan (cairan sampel yang telah disentrifugasi) dicampurkan dengan $2 \mathrm{~mL}$ larutan Bradford dalam kuvet. Campuran tersebut kemudian dihomogenasi menggunakan vortex mixer selama 10 detik. Campuran didiamkan selama 10 menit sebelum dilakukan pengukuran menggunakan spektrofotometri pada panjang gelombang $595 \mathrm{~nm}$.

\section{Rancangan Percobaan dan Analisis Statistik}

Rancangan percobaan yang digunakan pada penelitian ini adalah faktorial penuh untuk mempelajari pengaruh ukuran jerami, kelembapan awal, dan konsentrasi $\mathrm{Cu}$. Masingmasing variabel dilakukan dalam 3 tingkat $(-1,0,+1)$. Hasil yang diperoleh dianalisis dengan bantuan perangkat lunak Minitab 15.1. Desain eksperimen faktorial penuh menentukan 12 tempuhan. Nilai tingkat (dalam kurung) dan nilai sebenarnya ditunjukkan pada Tabel 1 . Hasil yang diukur pada hari kultivasi ke-10 adalah aktivitas enzim lakase dan konsentrasi protein. Model yang didapatkan merupakan model linier dengan 8 koefisien yang ditunjukkan pada Persamaan. 1, dengan $Y$ adalah aktivitas enzim/ berat kering (IU/g), $A$ adalah ukuran jerami, $B$ adalah kelembapan $(\% \mathrm{w} / \mathrm{w})$, dan $C$ adalah konsentrasi $\mathrm{Cu}(\mathrm{mM})$.

$Y=a+b A+c B+d C+e A^{*} B+f A * C+g B^{*} C+$ $h A^{*} B^{*} C$.

\section{HASIL DAN PEMBAHASAN}

\section{Volume Larutan Penyangga Pengekstrak}

Proses ekstraksi enzim lakase merupakan hal yang penting dalam menghasilkan aktivitas tertinggi dan mendapatkan seluruh enzim lakase yang terdapat di dalam jamur dan medium penyangga jamur tersebut. Vikineswary dkk. (2006) menyatakan bahwa enzim lakase dapat terekstraksi secara optimal dengan menggunakan larutan penyangga asetat $\mathrm{pH} 4,8$ pada temperatur $25^{\circ} \mathrm{C}$.

Volume larutan penyangga pengekstrak divalidasi untuk menentukan volume yang tepat pada ekstraksi semua enzim lakase di dalam medium fermentasi. Larutan penyangga divariasikan dalam tiga volume yaitu 50 $\mathrm{mL}, 100 \mathrm{~mL}$, dan $150 \mathrm{~mL}$, dengan variasi percobaan yang sama (ukuran jerami $0,5 \mathrm{~cm}$, kelembapan $61 \%$, dan konsentrasi $\mathrm{Cu} 0,1 \mathrm{mM}$ ).

Uji validitas larutan penyangga pengekstrak dilakukan dengan dua metode yaitu grafik interval plot (Gambar 1) dan uji-t pada 2 sampel. Gambar 1 menunjukkan bahwa penambahan volume larutan penyangga pada rentang 50-150 mL tidak berpengaruh signifikan terhadap aktivitas enzim/berat kering. Hasil uji-t menunjukkan tidak ada perbedaan signifikan antara volume larutan penyangga 50,100 , dan $150 \mathrm{~mL}$. 


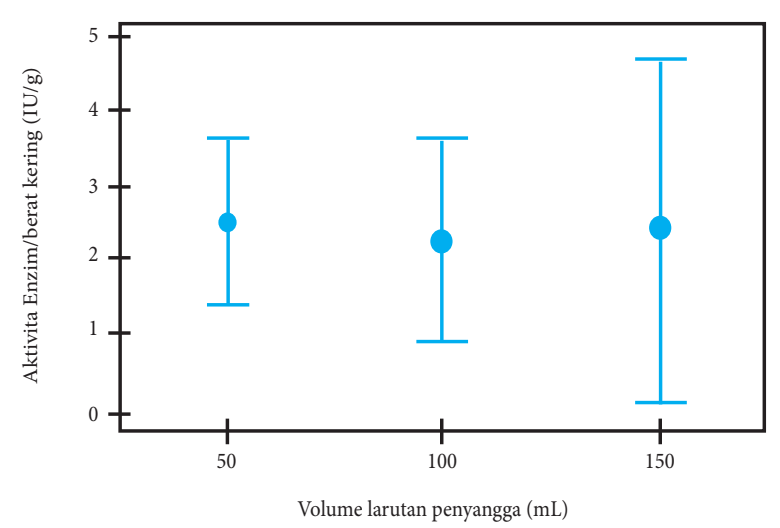

Gambar 1. Pengaruh Volume Larutan Penyangga terhadap Aktivitas Enzim

\section{Pertumbuhan Marasmius sp. pada Subtrat Jerami}

Sumber karbon yang dapat digunakan untuk pertumbuhan jamur pelapuk putih bervariasi. Sumber karbon yang umum digunakan adalah glukosa. Namun gliserol dapat digunakan sebagai sumber karbon pengganti. Pada penggunaan gliserol, jamur Marasmius sp. dapat tumbuh dengan baik. Aktivitas Marasmius sp. mulai terlihat pada hari ketiga pertumbuhan dan mencapai maksimum pada hari kesepuluh (Risdianto dkk., 2012).
Pada penelitian ini, Marasmius sp. dapat tumbuh dengan baik seperti yang telah disebutkan sebelumnya. Pada hari kesepuluh, Marasmius sp. menyelubungi seluruh jerami (Gambar 2). Aktivitas lakase pada berbagai ukuran jerami, kelembapan dan konsentrasi $\mathrm{Cu}$ disajikan pada Tabel 1. Aktivitas enzim lakase maksimum yang diperoleh dengan penggunaan sumber karbon gliserol mencapai 4,45 IU/g.

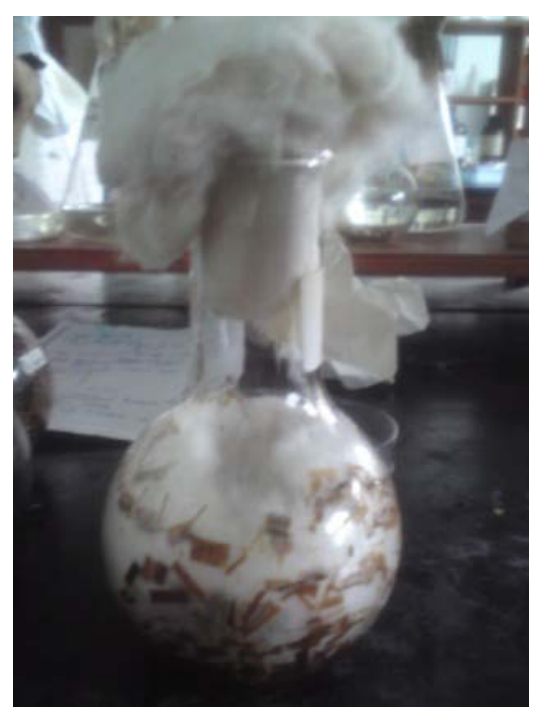

Gambar 2. Pertumbuhan Marasmius sp. pada Hari Kesepuluh

Tabel 1. Desain Eksperimen Faktorial Penuh dan Aktivitas Lakase

\begin{tabular}{cccccc}
\hline Tempuhan & $\begin{array}{c}\text { Ukuran jerami } \\
(\mathrm{cm})\end{array}$ & $\begin{array}{c}\text { Kelembapan } \\
(\%)\end{array}$ & $\begin{array}{c}\text { Konsentrasi Cu} \\
(\mathrm{mM})\end{array}$ & $\begin{array}{c}\text { Aktivitas enzim/ } \\
\text { berat kering substrat } \\
(\mathrm{IU} / \mathrm{g})\end{array}$ & $\begin{array}{c}\text { Konsentrasi } \\
\text { protein } \\
(\mathrm{g} / \mathrm{g})\end{array}$ \\
\hline 1 & $0,5(-1)$ & $61(-1)$ & $0,1(-1)$ & 2,28 & $3,4 \cdot 10^{-3}$ \\
2 & $4(+1)$ & $61(-1)$ & $0,1(-1)$ & 4,45 & $4,4 \cdot 10^{-3}$ \\
3 & $0,5(-1)$ & $82(+1)$ & $0,1(-1)$ & 1,97 & $2,8 \cdot 10^{-3}$ \\
4 & $4(+1)$ & $82(+1)$ & $0,1(-1)$ & 1,57 & $3,9 \cdot 10^{-3}$ \\
5 & $0,5(-1)$ & $61(-1)$ & $0,3(+1)$ & 0,52 & $3,7 \cdot 10^{-3}$ \\
6 & $4(+1)$ & $61(-1)$ & $0,3(+1)$ & 1,48 & $1,6 \cdot 10^{-3}$ \\
7 & $0,5(-1)$ & $82(+1)$ & $0,3(+1)$ & 0,06 & $2,0 \cdot 10^{-3}$ \\
8 & $4(+1)$ & $82(+1)$ & $0,3(+1)$ & 0,43 & $1,5 \cdot 10^{-3}$ \\
9 & $2,5(0)$ & $75(0)$ & $0,2(0)$ & 0,76 & $3,1 \cdot 10^{-3}$ \\
10 & $2,5(0)$ & $75(0)$ & $0,2(0)$ & 0,80 & $3,8 \cdot 10^{-3}$ \\
11 & $2,5(0)$ & $75(0)$ & $0,2(0)$ & 1,03 & $3,9 \cdot 10^{-3}$ \\
12 & $2,5(0)$ & $75(0)$ & $0,2(0)$ & 0,82 & $3,3 \cdot 10^{-3}$ \\
13 & 0,5 & 61 & 0 & 0,67 & $6,1 \cdot 10^{-3}$ \\
14 & 4 & 61 & 0 & 0,98 & $2,5 \cdot 10^{-3}$ \\
\hline
\end{tabular}




\section{Pengaruh Ukuran Jerami pada Aktivitas Lakase}

Ukuran jerami memiliki pengaruh dalam proses produksi enzim lakase. Partikel yang lebih kecil menyediakan luas permukaan kontak antara partikel dan miseliajamur yang lebih luas sehingga proses fermentasi dapat berlangsung dengan efisien. Walaupun memberikan efek yang baik, partikel dengan ukuran yang terlalu kecil dapat menyebabkan akumulasi substrat (penggumpalan substrat) yang dapat mengganggu proses distribusi udara ke dalam medium penyangga. Hal ini dapat menyebabkan proses respirasi dari jamur terganggu sehingga pertumbuhan jamur akan terganggu. Efek yang berlawanan ditunjukkan oleh partikel dengan ukuran yang lebih besar. Makin besar ukuran partikel akan mengakibatkan peningkatan fraksi ruang kosong antar partikel sehingga mempermudah difusi oksigen, namun dapat mengurangi luas kontak antara permukaan partikeldengan miselia jamur(Pandey dkk., 1999). Penelitian lain menunjukkan makin tinggi ukuran jerami, makin tinggi aktivitas enzim. Ukuran optimum jerami yang digunakan sebagai medium penyangga untuk produksi enzim-enzim ligninolitik adalah 1,68 mm (Hu dan Duvnjak, 2004).

Pada penelitian ini, aktivitas lakase yang dihasilkan pada proses fermentasi dengan ukuran medium penyangga $0,5 \mathrm{~cm}, 2,5 \mathrm{~cm}$, dan $4 \mathrm{~cm}$ tidak memberikan selisih yang signifikan. Hasil analisis statistik memberikan nilai $\mathrm{P}$ mencapai 0,280 dan 0,711 (Nilai $p>\alpha$ ) yang menunjukkan bahwa tidak ada perbedaan signifikan antara peningkatan ukuran. Hal ini menunjukkan bahwa Marasmius sp. dapat tumbuh dengan baik dan menghasilkan lakase pada semua ukuran jerami yang digunakan yaitu $0,5-4 \mathrm{~cm}$. Pada ukuran tersebut, miselia jamur dapat menggunakan nutrien yang ada di jerami sehingga dapat digunakan untuk pertumbuhan dan menghasilkan lakase

\section{Pengaruh Kelembapan pada Aktivitas Lakase}

Berdasarkan penelitian Patel dkk. (2009), aktivitas enzim lakase optimum didapatkan pada kelembapan awal 40-60\%. Pada kadar kelembapan di atas $60 \%$, aktivitas enzim lakase mulai mengalami penurunan. Pada penelitian ini, kadar kelembapan 61\% memberikan aktivitas enzim lakase paling baik. Peningkatan kadar kelembapan menjadi $75 \%$ dan $82 \%$ memberikan pola berupa penurunan aktivitas enzim lakase yang diproduksi (Gambar 3). Hal ini disebabkan karena ada korelasi antara kadar kelembapan dengan difusivitas oksigen ke dalam medium fermentasi.

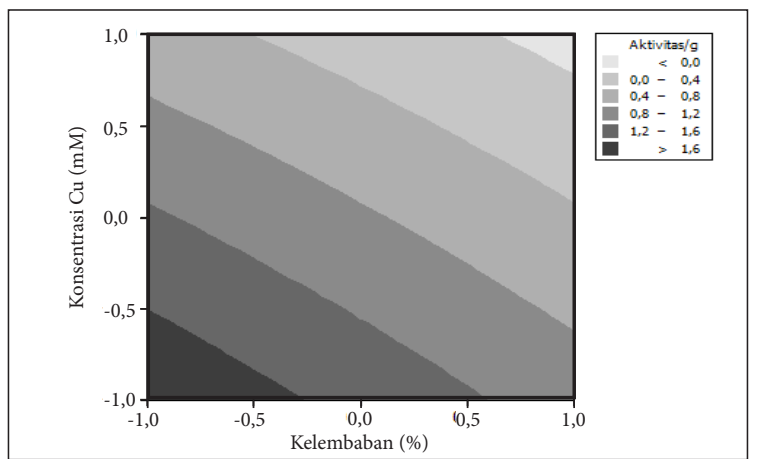

Gambar 3. Pengaruh Kelembapan dan

Konsentrasi $\mathrm{Cu}$ terhadap Aktivitas Enzim

Penurunan tersebut berhubungan dengan peningkatan jumlah fasa cair yang terdapat di dalam labu tempat berlangsungnya fermentasi, yang mengganggu difusi oksigen. Peningkatan kadar kelembapan awal menyatakan peningkatan jumlah cairan yang ditambahkan pada substrat kering awal di dalam labu. Penambahan air yang makin banyak dapat menurunkan porositas (ruang kosong) pada medium fermentasi. Hal tersebut dapat mengakibatkan hambatan transfer oksigen secara difusional. Penyebaran oksigen menjadi tidak merata sehingga ada bagian jamur yang tidak medapatkan pasokan oksigen yang cukup. Kekurangan oksigen dapat menyebabkan penurunan kinerja jamur dalam produksi enzim dan pertumbuhan (Hu dan Duvnjak, 2004). Kelembapan optimum rata-rata untuk jamur berfilamen adalah $40-70 \%$. Kelembapan optimum tersebut berbeda-beda untuk tiap jenis mikroorganisme (Raimbault, 1998).

Selain itu, keberadaan air dalam substrat mempengaruhi pengembangan (swelling) dan kemudahan absorpsi nutrien dalam substrat yang dapat digunakan mikroorganisme untuk pertumbuhan dan aktivitas metabolisme. Hasil penelitian ini sejalan dengan Ibrahim dkk. (2012) yang meyatakan bahwa produksi enzim (mananse) dalam fermentasi kultur sangat baik pada kelembapan yang optimum. Kadar kelembapan yang lebh rendah akan mengurangi solubilitas nutrien dalam substrat dan mempengaruhi pertumbuhan awal jamur. 


\section{Pengaruh Konsentrasi $\mathrm{Cu}$ pada Aktivitas Lakase}

Lakase merupakan enzim ekstraselular yang diinduksi oleh logam tembaga $(\mathrm{Cu})$. Beberapa penelitian menyatakan bahwa konsentrasi $\mathrm{Cu}$ makin besar (dalam rentang tertentu) dapat menginduksi jamur untuk memproduksi enzim dengan lebih baik. Kadar $\mathrm{Cu}$ yang disampaikan oleh peneliti-peneliti sebelumnya bervariasi. Kadar $\mathrm{Cu}$ sebesar $1 \mathrm{mM}$ dapat meningkatkan produksi enzim lakase oleh Trametes trogii (Levin dkk., 2002). Pada produksi enzim lakase menggunakan jamur Pleurotus ostreatus menunjukkan aktivitas enzim lakase tertinggi (14189 IU/g substrat kering) pada penambahan logam $\mathrm{Cu}$ dengan konsentrasi $0,28 \mathrm{mM}$ (Raimbault, 1998).

Penelitian ini menunjukkan produksi enzim lakase mempunyai aktivitas lakase optimum pada konsentrasi $\mathrm{Cu}$ 0,1 $\mathrm{mM}$. Tanpa adanya $\mathrm{Cu}$ dalam medium, aktivitas enzim lakase tetap terlihat namun dengan aktivitas yang rendah. Pada konsentrasi $\mathrm{Cu}$ diatas $0,1 \mathrm{mM}$, aktivitas enzim lakase mulai menurun (Gambar 4).

Logam $\mathrm{Cu}$ dapat menginduksi pembentukan enzim lakase, namun penambahan logam $\mathrm{Cu}$ yang berlebihan dapat menimbulkan dampak negatif pada mikroorganisme. Pada produksi enzim lakase menggunakan Trametes trogii, penambahan $\mathrm{Cu}$ dengan konsentrasi 1,5 $\mathrm{mM}$ menurunkan laju pertumbuhan maksimum dari mikroorganisme tersebut. Selain itu, penelitian tersebut juga menyatakan bahwa penambahan $\mathrm{Cu}$, walaupun tidak mempengaruhi aktivitas enzim lakase yang dihasilkan, mempengaruhi sistem protein lain yang dihasilkan (Levin dkk. 2002). Menurut Niladevi dkk. (2007), kadar Cu yang lebih tinggi pada medium merupakan racun bagi mikroorganisme.

Berdasarkan analisis data secara statistik, pengaruh variabel-variabel dapat dinyatakan dengan persamaan (2)

$Y=2,277+0,167 A-0,405 B-0,628 C-0,610$ $A^{*} C$

dengan $Y$ adalah aktivitas enzim/berat kering $(\mathrm{IU} / \mathrm{g}), \quad A$ adalah ukuran jerami, $B$ adalah kelembapan (\%), dan $C$ adalah konsentrasi $\mathrm{Cu}(\mathrm{mM})$.

Aktivitas lakase yang diperoleh dari penelitian ini relatif rendah bila dibandingkan dengan hasil penelitian lain yang sejenis menggunakan gliserol sebagai sumber karbon dan waktu kultivasi 10 hari seperti disajikan dalam Tabel 2.

\section{Hasil Scanning Electron Microscopy (SEM)}

Pengamatan menggunakan Scanning Electron Microscopy (SEM) dilakukan untuk melihat struktur jerami setelah proses fermentasi berlangsung. Gambar 5.a memperlihatkan struktur jerami sebelum fermentasi, dengan perbesaran 1000 kali. Setelah proses fermentasi, miselia Marasmius sp. mampu menembus struktur jerami, seperti yang diperlihatkan pada Gambar 5.b. Pada gambar tersebut, struktur jerami terlihat lebih berlubang dibandingkan sebelum fermentasi. Hal ini mengindikasikan bahwa Marasmius sp. mampu memecah struktur lignin, sehingga miselianya mampu menembus matriks lignoselulosa. Matriks struktur jerami setelah proses fermentasi hampir seluruhnya ditutupi oleh miselia jamur Marasmius sp. (Gambar $5 \mathrm{~d}$ dan f).

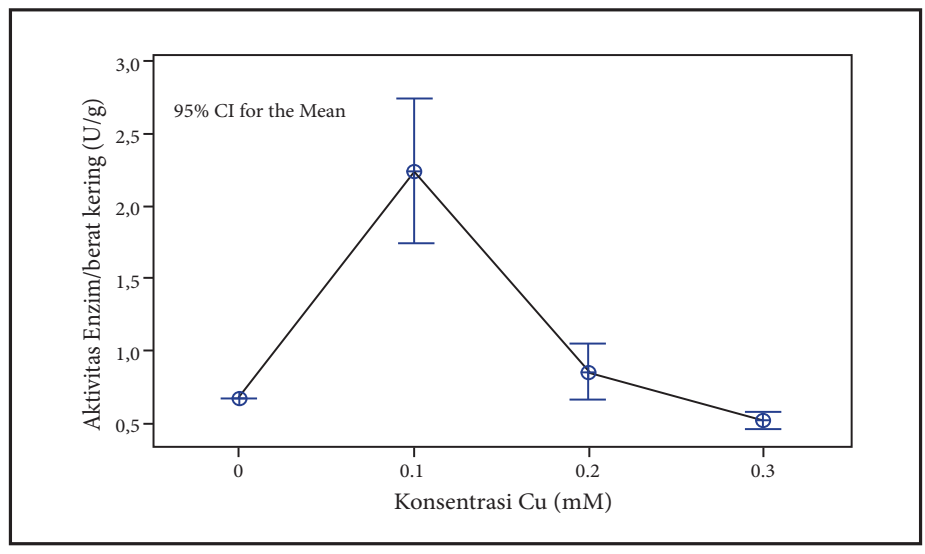

Gambar 4. Pengaruh Konsentrasi Cu terhadap Aktivitas Lakase 
Tabel 2. Perbandingan dengan Penelitian Lain

\begin{tabular}{lcl}
\hline \multicolumn{1}{c}{ Jamur Pelapuk Putih } & Aktivitas Lakase (U/mL) & \multicolumn{1}{c}{ Peneliti } \\
\hline Cerena unicolor 300 & 18,5 & Elisahvili dan Kachlishvili, 2009 \\
Coriolopsis gallica 1184 & 9,3 & Elisahvili dan Kachlishvili, 2009 \\
Ganoderma lucidum 158 & 0,3 & Elisahvili dan Kachlishvili, 2009 \\
Ganoderma applanatum 107 & 0,2 & Elisahvili dan Kachlishvili, 2009 \\
Trametes archarea 7 & 1,8 & Elisahvili dan Kachlishvili, 2009 \\
Trametes versicolor 775 & 14,8 & Elisahvili dan Kachlishvili, 2009 \\
Trichaptum biforme 117 & 1,9 & Elisahvili dan Kachlishvili, 2009 \\
Marasmius sp. & 1,25 & Penelitian ini \\
\hline
\end{tabular}

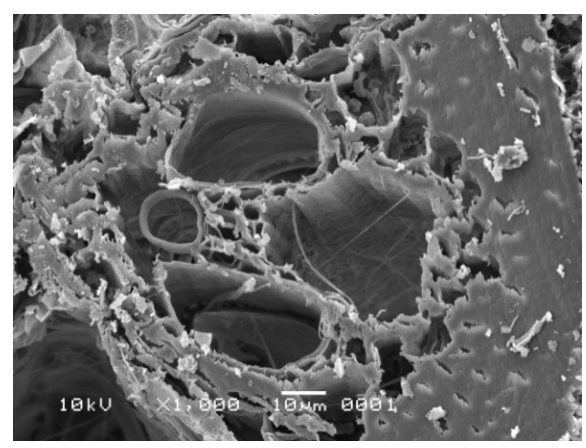

(a)

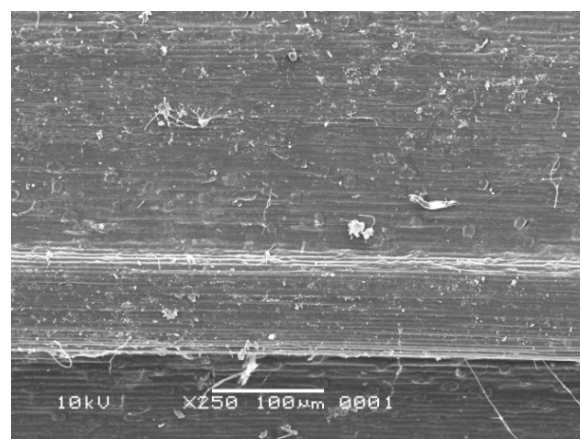

(c)

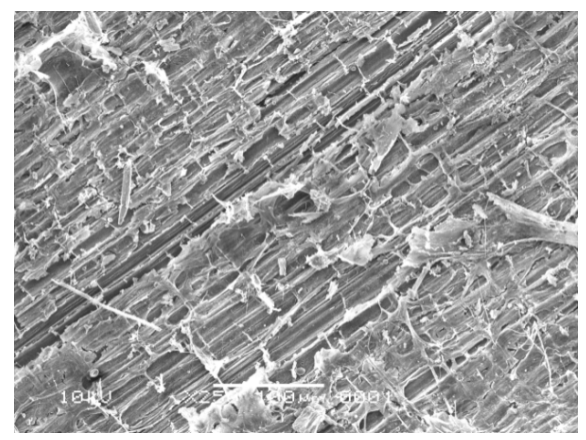

(e)

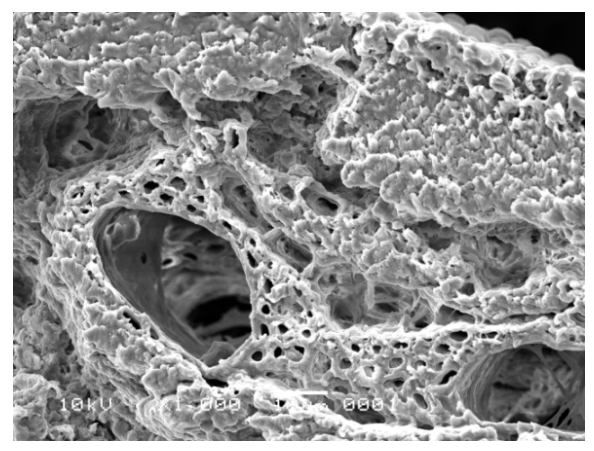

(b)

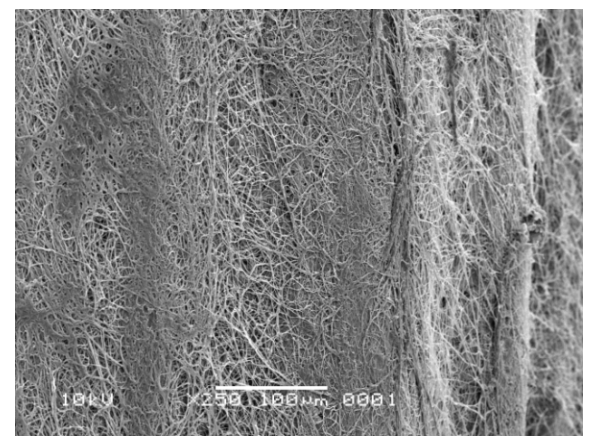

(d)

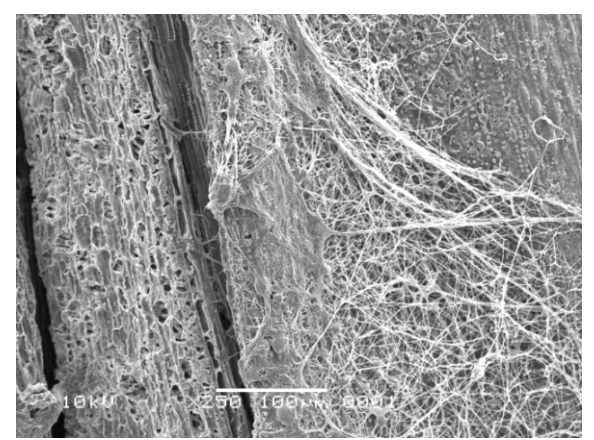

(f)

Gambar 5. Hasil SEM pada Berbagai Ukuran dan Penampang Jerami : Pembesaran 1000 x Jerami Sebelum (a) dan Sesudah Fermentasi (b), Penampang Luar Jerami Pembesaran 250 x Jerami Sebelum (c) dan Sesudah Fermentasi (d), Penampang Melintang Jerami Pembesaran 250 x Jerami Sebelum (e) dan Sesudah Fermentasi (f) 


\section{KESIMPULAN}

Volume larutan penyangga asetat $\mathrm{pH}$ 4,6 yang digunakan untuk mengekstrak cukup dengan $50 \mathrm{~mL}$. Kondisi optimum produksi enzim lakase menggunakan Marasmius sp. pada fermentasi kultur padat adalah kelembapan awal $61 \%$ dan konsentrasi $\mathrm{Cu} 0,1 \mathrm{mM}$, ukuran jerami tidak memberikan pengaruh signifikan terhadap aktivitas enzim yang diproduksi. Marasmius sp. dapat mengurai lignoselulosa hingga menembus matriks lignin selulosa.

\section{UCAPAN TERIMA KASIH}

Terima kasih kepada Kementerian Negara Riset dan Teknologi dan Pusat Penelitian dan Pengembangan Geologi Kelautan Bandung (PPGL) yang membantu menyediakan hasil analisis SEM.

\section{DAFTAR PUSTAKA}

Da Silva, G.P., Mack, M., Contiero, J., 2009, Glycerol: A promising and abundant carbon source for industrial microbiology, Biotechnology Advances, 27, 30-39

Departemen Pertanian Indonesia, "www.litbang. deptan.go.id", 2009

Elisashvili, V., Kachlishvili, E., 2009, Physiological regulation of laccase anad manganese peroxidase production by white-rot Basidiomycetes, Journal of Biotechnology, 144, 37-42

Hu, J., Duvnjak, Z., 2004, The production of a laccase and the decrease of the phenolic content in canola meal during the growth of the fungus Pleurotus ostreatus in solid state fermentation processes. Eng. Life Sci., 4(1), 50-55

Ibrahim, D., Puspitaloka, H., Rahim, R.A., Hong, L.S., 2012, Characterization of solid state fermentation culture conditions for growth and mananase production by Aspergillus niger USM F4 on rice husk in tray system, British Biotechnology Journal, 2(3), 133145

Levin, L, Forchiassin, F., Ramos, A.M., 2002, Copper induction of lignin-moifying enzymes in the white-rot fungus Trametes trogii, Mycologia, 94(3), 377-383
Mayer, A.M., Staples, R.C., 2002, Laccase: new functions for an old enzyme, Phytochemistry, 60, 551-565.

Niku-Paavola M-L, Karhunen E, Salola P, Raunio V. 1988. Ligninolytic enzymes of the white-rot fungus Phlebia radiata. Biochem J. 254:877-884

Niladevi, K.N., Sukumaran, R.K., Prema, P., 2007, Utilization of rice straw for laccase production by Streptomyces psammoticus in solid state fermentation. J. Ind Microbiol Biotechnol, 34, 665-674

Pandey, A., Selvakumar, P., Soccol, C.R., dan Nigam, P., 1999, Solid State Fermentation for the Production of Industrial Enzymes, Curr. Sci., 77, 149-162

Patel, H., Gupte, A., Gupte, S., 2009, Effect of different culture and inducers on production of laccase by a Basidiomycete fungal isolate Pleurotus ostreatus HP-1 under Solid State Fermentation, Bioresources, 4(1), 268-284

Rimbault, M., 1998, General and microbiological aspects of solid state fermentation. Electonic Journal of Biotechnology, 1(3), 174-188

Risdianto, H., Sofianti, E., Suraya, Suhardi, S.H., Setiadi, T., 2011, The influence of carbon sources on laccase production by white rot fungus Marasmius sp. in solid state fermentation. Prosiding Regional Symposium of Chemical Engineering 2011, Ho Chi Minh City, Vietnam, IND-01-001, hal 1-7

Risdianto, H., Sofianti, E., Suhardi, S.H., Setiadi, T., 2012. Optimisation of laccase production using white rot fungi and agriculture wastes in solid state fermentation. ITB Journal of Engineering Science, 44B(2), 93-106

Sanchez, C., 2009, Lignocellulosic residues: Biodegradation and bioconversion by fungi, Biotechnology Advances, 27, 185-194

Sierra, R., Smith, A., Cesar, G., Holtzapple, M.T., 2010, Producing Fuels and Chemicals from Lignocellulosic Biomass, SBE Special Edition-Biofuels, S10-S18

Vikineswary, S., Noorlidah Abdullah, M. Renuvathani, M. Sekaran, A. Pandey, E.B.G. Jones, 2006, Productivity of laccase in solid substrate fermentation of selected agro-residues by Pycnoporus sanguineus, Bioresources Technology, 97, 171-177. 